\title{
A novel PCR-based point-of-care method enables rapid, sensitive and reliable diagnosis of Babesia gibsoni infection in dogs
}

\author{
I-Li Liu ${ }^{1+}$, Nai-Yu Chi ${ }^{2+}$, Chia-Ling Chang ${ }^{2}$, Ming-Long Hung ${ }^{2}$, Chun-Ta Chiu ${ }^{3}$ and Hui-Wen Chen ${ }^{3^{*}}$ (1)
}

\begin{abstract}
Background: Babesia gibsoni (B. gibsoni) is an intraerythrocytic protozoan parasite of dogs that causes fever and hemolytic illness. A timely diagnosis is essential for the disease management.

Results: Here, we report a QubeMDx PCR system which enables a rapid, sensitive and reliable diagnosis of $B$. gibsoni near the dog patient. Within 30 min, this diagnostic assay was able to detect as low as $0.002 \%$ parasitemia of the dog blood. Using clinical samples, this new assay was validated to demonstrate $100 \%$ agreement with realtime PCR.

Conclusions: This novel diagnostic method provides a reliable point-of-care test to assist in the identification of $B$. gibsoni.
\end{abstract}

Keywords: Babesia gibsoni, Point-of-care, QubeMDx PCR system, Real-time PCR

\section{Background}

Babesia gibsoni (B. gibsoni) is a widespread ticktransmitted protozoan blood parasite that was first identified in 1910 in dogs and jackals from India and now prevalent in many regions, including Taiwan $[1,2]$ and other Asian countries such as Japan [3], Korea [4], China [5], Bangladesh [6], India [7] and Malaysia [8]. B. gibsoni infection is frequently found in companion dogs and presents a serious clinical problem in the world. The clinical severity of $B$. gibsoni infection in dogs is agedependent and potentially life-threatening with clinical symptoms ranging from remittent fever and severe hemolytic illness. Therefore, the diagnosis of this disease and the detection of dogs that carry this blood parasite are very important [9-12].

Generally, the standard method for definitive means of diagnosis of babesiosis is microscopic examination of blood smears following Giemsa-staining for visual

\footnotetext{
* Correspondence: winnichen@ntu.edu.tw

${ }^{+}$-Li Liu and Nai-Yu Chi contributed equally to this work.

${ }^{3}$ Department of Veterinary Medicine, National Taiwan University, 1 Sec 4

Roosevelt Rd, Taipei, Taiwan

Full list of author information is available at the end of the article
}

identification of parasites. Although this microscopic method is an inexpensive diagnostic test, the detection of $B$. gibsoni in erythrocytes on blood smears is sometimes difficult and may be error-prone. As B. gibsoni is a small and pleomorphic organism (1-3 $\mu \mathrm{m}$ in diameter), unlike the large, paired and teardrop-shaped Babesia canis, a highly experienced diagnostic skill is required to distinguish it from artifacts under the microscope, and it becomes even more challenging to find the parasites when an infected dog has low levels of parasitemia [12]. On the other hand, the molecular diagnosis detecting the DNA of B. gibsoni in canine blood samples by polymerase chain reaction (PCR) offers high degrees of detection sensitivity and specificity. Various conventional [13], nested [14] and real-time [15] PCR assays detecting B. gibsoni infection in dogs have been developed. However, these assays mostly require a relatively expensive thermo cycler and well-trained personnel, which may delay results and add costs. As a result, a rapid, affordable and user-friendly platform is needed for a point-ofcare (POC) detection of $B$. gibsoni in daily veterinary

(c) The Author(s). 2019 Open Access This article is distributed under the terms of the Creative Commons Attribution 4.0 International License (http://creativecommons.org/licenses/by/4.0/), which permits unrestricted use, distribution, and reproduction in any medium, provided you give appropriate credit to the original author(s) and the source, provide a link to the Creative Commons license, and indicate if changes were made. The Creative Commons Public Domain Dedication waiver (http://creativecommons.org/publicdomain/zero/1.0/) applies to the data made available in this article, unless otherwise stated. 
practice to facilitate animal care and disease management.

The recently developed QubeMDx (Credo Biomedical Pte. Ltd., Singapore) is a portable diagnostic system $(12.1 \times 10.9 \times 14.7 \mathrm{~cm}, \mathrm{H} \times \mathrm{W} \times \mathrm{D})$ using reaction tubes prefilled with fluorescence-based reagents to facilitate the real-time PCR detection process within $15 \mathrm{~min}$. The programmed device allows users to perform four different targeted DNA or RNA molecular diagnosis in a given round of reaction with minimal training. The purpose of the present study is to evaluate the QubeMDx PCR system as a practical and accurate method for the diagnosis of B. gibsoni infection in dog by using clinical canine blood samples and comparing to a standard realtime PCR assay.

\section{Results}

As illustrated in Fig. 1a, the DNA extraction can be completed within $8 \mathrm{~min}$. The resultant DNA solution was subsequently assayed using the QubeMDx PCR device (Fig. 1b). After 15-min reaction time, the test result for B. gibsoni was displayed in the panel A, either positive $(+)$ or negative $(-)$ on the screen, and the test validity (internal control) was displayed in the panel $B$ (Fig. 1c). Evaluated using 28 reference test (real-time PCR)-positive clinical samples, the sensitivity of the QubeMDx PCR was $100 \%$. The specificity was also
$100 \%$, calculated using 27 reference test-negative samples. The Kappa value was 1 , indicating highly reproducible results between these two methods. Furthermore, among different levels of parasitemia analyzed from 28 positive dog samples (Table 1), the QubeMDx PCR system successfully detected the B. gibsoni ranging from 94 to 398,000 parasites/ $\mu \mathrm{L}$ of blood $(0.002$ to $8 \%$ of parasitemia). Importantly, no discrepancy between these two methods was found among these clinical samples containing low levels of parasitemia $(16 / 28)(<5000$ parasites $/ \mu \mathrm{L}$ of blood or parasitemia $<0.1 \%)$. Using ten-fold serially diluted blood sample (dog \#25), the QubeMDx PCR was shown to be able to detect $0.00576 \%$, but not $0.000576 \%$ of parasitemia (Fig. 2). Collectively, DNA rapid extraction and QubeMDx PCR allow for detection of the B. gibsoni DNA with a sensitivity limit in between 0.000576 and $0.002 \%$ of parasitemia. The analytical specificity of the QubeMDx PCR for B. gibsoni detection was further assessed using blood samples positive for Anaplasma platys, Ehrlichia canis or Babesia canis. As indicated in Additional file 1: Table S1, no false positive detection results were obtained from canine blood samples infected with other three pathogens.

\section{Discussion}

In this study, a novel and reliable POC diagnostic method for B. gibsoni detection was reported. By

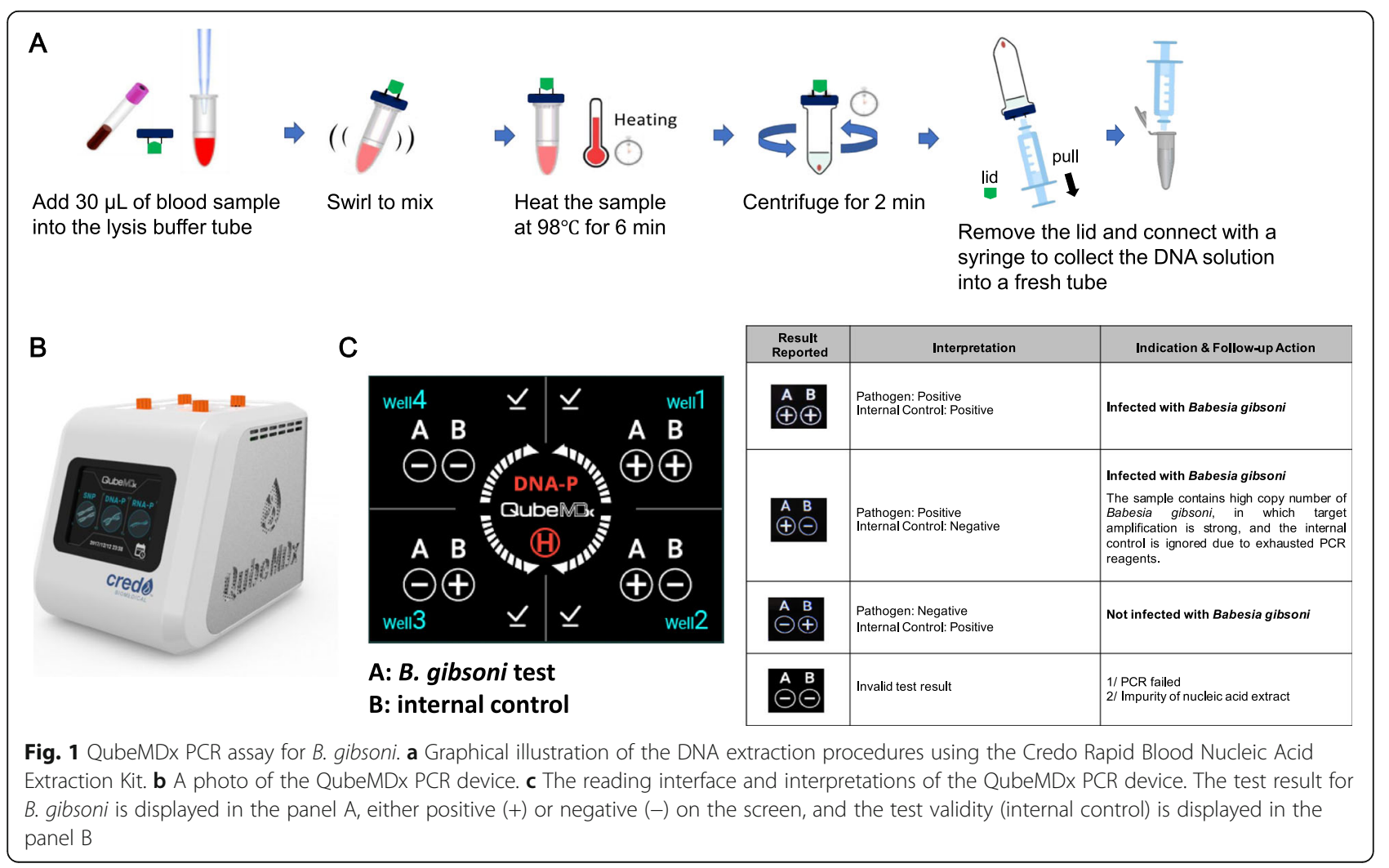


Table 1 B. gibsoni-positive dog blood samples included in this study

\begin{tabular}{|c|c|c|c|c|c|c|c|}
\hline \multirow[t]{2}{*}{ No. } & \multirow{2}{*}{$\begin{array}{l}\text { Age } \\
(y r)\end{array}$} & \multirow[t]{2}{*}{ Sex } & \multirow[t]{2}{*}{ Breed } & \multirow{2}{*}{$\begin{array}{l}\mathrm{PCV}^{\mathrm{a}} \\
(\%)\end{array}$} & \multicolumn{2}{|l|}{ Test results } & \multirow{2}{*}{$\begin{array}{l}\text { Parasites/ } \\
\mu \mathrm{L} \text { of } \\
\text { blood }^{b}\end{array}$} \\
\hline & & & & & QubeMDx & Real-time PCR & \\
\hline 1 & 8 & M & Mixed & $n / a$ & + & + & 94 \\
\hline 2 & 7 & M & $\mathrm{n} / \mathrm{a}$ & 32.3 & + & + & 98 \\
\hline 3 & 12 & $\mathrm{~F}$ & Mixed & 28.8 & + & + & 103 \\
\hline 4 & 13 & M & Mixed & 21.3 & + & + & 188 \\
\hline 5 & 4.3 & $\mathrm{~F}$ & Mixed & 50.5 & + & + & 249 \\
\hline 6 & 1.7 & M & Miniature Schnauzer & 23.6 & + & + & 261 \\
\hline 7 & 14 & $\mathrm{~F}$ & Mixed & 27.3 & + & + & 422 \\
\hline 8 & 9 & $\mathrm{~F}$ & Mixed & 31.8 & + & + & 798 \\
\hline 9 & 2 & $\mathrm{~F}$ & Mixed & $\mathrm{n} / \mathrm{a}$ & + & + & 1030 \\
\hline 10 & 5 & M & Poodle & 37.8 & + & + & 1150 \\
\hline 11 & 8 & M & Mixed & 48.7 & + & + & 1290 \\
\hline 12 & 6 & $\mathrm{~F}$ & Mixed & $\mathrm{n} / \mathrm{a}$ & + & + & 1360 \\
\hline 13 & 5 & M & Poodle & 37.7 & + & + & 1870 \\
\hline 14 & 6 & $\mathrm{~F}$ & Mixed & $\mathrm{n} / \mathrm{a}$ & + & + & 2180 \\
\hline 15 & 5 & $\mathrm{~F}$ & Mixed & $\mathrm{n} / \mathrm{a}$ & + & + & 3610 \\
\hline 16 & 9 & M & Labrador Retriever & 25.9 & + & + & 3840 \\
\hline 17 & 4 & $\mathrm{~F}$ & Mixed & 43.9 & + & + & 5410 \\
\hline 18 & 6 & M & Poodle & 47.3 & + & + & 8140 \\
\hline 19 & 3 & M & Poodle & 14.6 & + & + & 8140 \\
\hline 20 & 2 & $\mathrm{~F}$ & Mixed & 51.2 & + & + & 8760 \\
\hline 21 & 0.2 & $\mathrm{~F}$ & Mixed & 30.3 & + & + & 10,100 \\
\hline 22 & 12 & $\mathrm{~F}$ & Miniature Schnauzer & 16.7 & + & + & 10,800 \\
\hline 23 & 9 & $\mathrm{~F}$ & Mixed & $\mathrm{n} / \mathrm{a}$ & + & + & 13,700 \\
\hline 24 & 6 & M & Corgi & 10.5 & + & + & 14,200 \\
\hline 25 & 2 & M & Pomeranian & 40.6 & + & + & 28,800 \\
\hline 26 & 12 & M & Dachshund & 16 & + & + & 30,400 \\
\hline 27 & 0.5 & M & Bichon Frisé & 18.6 & + & + & 149,000 \\
\hline 28 & 10 & M & Maltese & 14.6 & + & + & 398,000 \\
\hline
\end{tabular}

apacked cell volume

bParasites was determined by real-time PCR and calculated from the standard curve constructed with the plasmid DNA according to Matsuu et al., 2005 [15]

Ten-fold serial dilutions of dog blood (Dog \#25*)
Fig. 2 Detection limit of QubeMDx PCR assay for B. gibsoni. B. gibsosi-positive dog blood (0.576\% of parasitemia according to the real-time PCR)
was 10-fold serially diluted and tested onto the QubeMDx PCR system to determine the detection limit. The test result for B. gibsoni is displayed
in the panel A, with positive (+) or negative (-) result. The test validity (internal control) is displayed in the panel B


coupling the Credo Rapid Blood Nucleic Acid Extraction Kit and the QubeMDx PCR system, the entire diagnostic procedures for B. gibsoni can be completed within 30 min in clinic, where veterinarians primarily rely on microscopic examination as the diagnosis method. The simplified assay procedures and saved time from laboratory identification may expedite the prescription medications and lead to effective disease management for the affected dogs.

The detection limit of diagnostic tests is a critical parameter for accurate and timely pathogen identification. It has been suggested that B. gibsoni infection with low parasitemia $(0-0.75 \%)$ is easily misdiagnosed as immune-mediated hemolytic anemia and sometimes inappropriately treated with immune suppressive drugs $[16,17]$. For dogs with babesiosis, either during the early or chronic stages of infection or under medical treatment, the parasite numbers in the blood may be low. Previous experimental infection study has shown that, not until 10 days after infection, dogs inoculated with $B$. gibsoni revealed a significantly decreased level of packed cell volume $(\mathrm{PCV})(<37 \%)$ or with a parasitemia greater than $0.1 \%$ [15]. By using this sensitive QubeMDx PCR system, the detection limit of $0.002 \%$ of parasitemia ( 94 parasites $/ \mu \mathrm{L}$ of blood) allows for early diagnosis of infected dogs. Although greater detection limit was previously demonstrated by the real-time PCR $(9$ parasites $/ \mu \mathrm{L}$ of blood) [15], recombinase polymerase amplificationlateral flow (LF-RPA) dipstick method (0.5 parasites $/ \mu \mathrm{L}$ of blood) [5], loop-mediated isothermal amplification (LAMP) $(0.0000135 \%$ of parasitemia) [18], the differences can be attributed to the use of rapid DNA extraction procedures in the QubeMDx system, leading to a compromised DNA yield.

In addition to a low detection limit, a $100 \%$ of sensitivity and specificity for B. gibsoni detection was achieved by this QubeMDx PCR based on real-time PCR confirmed positive/negative samples, while previously 86.67 and $57.33 \%$ of positive rate were obtained by the LF-RPA dipstick method [5] and the LAMP method [18], respectively, evaluated from clinically suspected dogs. Furthermore, the internal control included in each reaction of QubeMDx PCR provides an additional source for quality control. Taken together, compared to other available molecular methods, QubeMDx PCR system is a reliable POC method with advantages of rapidity and reaction simplicity.

\section{Conclusions}

This reported QubeMDx PCR system offers a rapid (<30 min), sensitive, and effective diagnosis for B. gibsoni in clinical infections. The present point-of-care testing allows for treatment prescription in the early stages of the infection, facilitating the recovery of affected dogs.

\section{Methods}

A total of 57 EDTA-anticoagulated canine whole blood samples were collected at the National Taiwan University Veterinary Hospital. For the reference test of $B$. gibsoni detection, total DNA was extracted from $100 \mu \mathrm{L}$ of blood sample with the DNeasy Blood \& Tissue Kit (Qiagen, Hilden, Germany) according to the manufacturer's instructions. A real-time PCR for B. gibsoni detection was performed to define the infection status and the standard curve was constructed with plasmid DNA for the conversion of parasitemia [15]. Through the reference test, 28 samples were defined as positive and used for the sensitivity evaluation for QubeMDx PCR system, whereas other 29 samples were negative and used for the specificity determination. In addition, the detection limit of the QubeMDx PCR system was determined using serially-diluted dog blood from one of the realtime PCR-positive blood sample. Furthermore, six canine whole blood samples diagnosed as Ehrlichia canis, Anaplasma platys or Babesia canis positive by PCR or real-time PCR [19-21] were also included in this study to evaluate the specificity of the QubeMDx PCR system.

To conduct the QubeMDx PCR assay, DNA was prepared by using the Credo Rapid Blood Nucleic Acid Extraction Kit (Credo Biomedical Pte. Ltd.). Briefly, $30 \mu \mathrm{L}$ of blood sample was added to the tube containing the lysis buffer and the mixture was heated at $98^{\circ} \mathrm{C}$ for $6 \mathrm{~min}$. After the heating, the reaction mix was fractionated via centrifugation, and total DNA in the supernatant was collected to a fresh tube. The resultant DNA solution was subsequently assayed using the QubeMDx Babesia gibsoni Detection Kit (Credo Biomedical Pte. Ltd.) according to the manufacturer's instructions. Briefly, $30 \mu \mathrm{L}$ of the DNA solution was added to the reaction tube prefilled with lyophilized reagents containing primers and fluorogenic probes targeting the p18 gene of $B$. gibsoni as well as PCR essential reagents and internal controls. Tubes were then loaded onto the QubeMDx PCR device, and the fluorescent signals during amplification were detected and processed by a built-in algorithm. The video demonstrating assay procedures was filmed and can be found in the following link: https://www. dropbox.com/s/nbdt9ryvuubxsea/QubeMDx.mp4?dl=0.

\section{Supplementary information}

Supplementary information accompanies this paper at https://doi.org/10. 1186/s12917-019-2181-5.

Additional file 1: Table S1. Analytical specificity results of the QubeMDx PCR for B. gibsoni. 


\section{Abbreviations}

B. gibsoni: Babesia gibsoni; LAMP: Loop-mediated isothermal amplification; LFRPA: Recombinase polymerase amplification-lateral flow; PCR: Polymerase chain reaction; PCV: Packed cell volume; POC: Point-of-care

\section{Acknowledgments}

Not applicable.

\section{Authors' contributions}

ILL, MLH and HWC designed the study. NYC, CLC, MLH and CTC performed the experiments. ILL, MLH and HWC analyzed the data. ILL, MLH and HWC wrote the manuscript. All authors read and approved the final manuscript.

\section{Funding}

This work was supported by Credo Biomedical Pte. Ltd. and National Taiwan University. The funders had no role in study design, data collection and analysis, decision to publish, or preparation of the manuscript.

\section{Availability of data and materials}

The data used and/or analyzed during the current study are available from the corresponding author on reasonable request.

\section{Ethics approval and consent to participate}

Samples used in this study were derived during medical practice in the National Taiwan University Veterinary Hospital (NTUVH) and the use of samples has been approved by dog owners and NTUVH with written consent. The ethics approval was waived according to the "Guideline for the Care and Use of Laboratory Animals" issued by Council of Agriculture Executive Yuan, Taiwan on June 22nd of 2018 and the official notice made by the Ministry of Health and Welfare, Taiwan on July 5th of 2012 (document number: 1010265083).

\section{Consent for publication}

Not applicable.

\section{Competing interests}

The authors declare that they have no competing interests.

\section{Author details}

${ }^{1}$ Institute of Veterinary Clinical Science, National Taiwan University, Taipei, Taiwan. ${ }^{2}$ Credo Biomedical Pte. Ltd., Singapore, Singapore. ${ }^{3}$ Department of Veterinary Medicine, National Taiwan University, 1 Sec 4 Roosevelt Rd, Taipei, Taiwan.

Received: 3 July 2019 Accepted: 19 November 2019

Published online: 29 November 2019

\section{References}

1. Lee CC, Hsieh YC, Huang CC, Tsang CL, Chung YT. Sequence and phylogenetic analysis of the thrombospondin-related adhesive protein (TRAP) gene of Babesia gibsoni isolates from dogs in Taiwan. J Vet Med Sci. 2010;72:1329-35

2. Liu PC, Lin YL, Lin CN, Su BL. A SimpleProbe((R)) real-time PCR assay for differentiating the cytochrome b M1211 mutation in clinical specimens from dogs infected with Babesia gibsoni. Ticks Tick Borne Dis. 2016;7:639-43.

3. Konishi K, Sakata Y, Miyazaki N, Jia H, Goo YK, Xuan X, et al. Epidemiological survey of Babesia gibsoni infection in dogs in Japan by enzyme-linked immunosorbent assay using B. gibsoni thrombospondin-related adhesive protein antigen. Vet Parasitol. 2008:155:204-8.

4. Suh GH, Ahn KS, Ahn JH, Kim HJ, Leutenegger C, Shin S. Serological and molecular prevalence of canine vector-borne diseases (CVBDs) in Korea. Parasit Vectors. 2017;10:146

5. Cui J, Zhao Y, Sun Y, Yu L, Liu Q, Zhan X, et al. Detection of Babesia gibsoni in dogs by combining recombinase polymerase amplification (RPA) with lateral flow (LF) dipstick. Parasitol Res. 2018;117:3945-51.

6. Terao M, Akter S, Yasin MG, Nakao R, Kato H, Alam MZ, et al. Molecular detection and genetic diversity of Babesia gibsoni in dogs in Bangladesh. Infect Genet Evol. 2015;31:53-60.

7. Singh MN, Raina OK, Sankar M, Rialch A, Tigga MN, Kumar GR, et al. Molecular detection and genetic diversity of Babesia gibsoni in dogs in India. Infect Genet Evol. 2016;41:100-6.
8. Mokhtar AS, Lim SF, Tay ST. Molecular detection of Anaplasma platys and Babesia gibsoni in dogs in Malaysia. Trop Biomed. 2013;30:345-8.

9. Taboada J, Merchant SR. Babesiosis of companion animals and man. Vet Clin North Am Small Anim Pract. 1991;21:103-23.

10. Conrad P, Thomford J, Yamane I, Whiting J, Bosma L, Uno T, et al. Hemolytic anemia caused by Babesia gibsoni infection in dogs. J Am Vet Med Assoc. 1991;199:601-5.

11. Casapulla R, Baldi L, Avallone V, Sannino R, Pazzanese L, Mizzoni V. Canine piroplasmosis due to Babesia gibsoni: clinical and morphological aspects. Vet Rec. 1998;142:168-9.

12. Boozer AL, Macintire DK. Canine babesiosis. Vet Clin North Am Small Anim Pract. 2003;33:885-904 viii.

13. Fukumoto S, Xuan X, Shigeno S, Kimbita E, Igarashi I, Nagasawa H, et al. Development of a polymerase chain reaction method for diagnosing Babesia gibsoni infection in dogs. J Vet Med Sci. 2001;63:977-81.

14. Birkenheuer AJ, Levy MG, Breitschwerdt EB. Development and evaluation of a seminested PCR for detection and differentiation of Babesia gibsoni (Asian genotype) and B. canis DNA in canine blood samples. J Clin Microbiol. 2003, 41:4172-7.

15. Matsuu A, Ono S, Ikadai H, Uchide T, Imamura S, Onuma M, et al. Development of a SYBR green real-time polymerase chain reaction assay for quantitative detection of Babesia gibsoni (Asian genotype) DNA. J Vet Diagn Invest. 2005;17:569-73.

16. Inokuma H, Okuda M, Yoshizaki Y, Hiraoka H, Miyama T, Itamoto K, et al. Clinical observations of Babesia gibsoni infection with low parasitaemia confirmed by PCR in dogs. Vet Rec. 2005;156:116-8.

17. Otsuka Y, Yamasaki M, Yamato O, Maede Y. The effect of macrophages on the erythrocyte oxidative damage and the pathogenesis of anemia in Babesia gibsoni-infected dogs with low parasitemia. J Vet Med Sci. 2002;64:221-6.

18. Mandal M, Banerjee PS, Kumar S, Ram H, Garg R, Pawde AM. Development of loop-mediated isothermal amplification (LAMP) for detection of Babesia gibsoni infection in dogs. Vet Parasitol. 2015:209:50-5.

19. Dalrymple BP, Casu RE, Peters JM, Dimmock CM, Gale KR, Boese R, et al. Characterisation of a family of multi-copy genes encoding rhoptry protein homologues in Babesia bovis, Babesia ovis and Babesia canis. Mol Biochem Parasitol. 1993:57:181-92.

20. da Silva CB, Pires MS, Vilela JA, Peckle M, da Costa RL, Vitari GL, et al. A new quantitative PCR method for the detection of Anaplasma platys in dogs based on the citrate synthase gene. J Vet Diagn Invest. 2016;28:529-35.

21. Nakaghi AC, Machado RZ, Ferro JA, Labruna MB, Chryssafidis AL, Andre MR, et al. Sensitivity evaluation of a single-step PCR assay using Ehrlichia canis p28 gene as a target and its application in diagnosis of canine ehrlichiosis. Rev Bras Parasitol Vet. 2010:19:75-9.

\section{Publisher's Note}

Springer Nature remains neutral with regard to jurisdictional claims in published maps and institutional affiliations.

Ready to submit your research? Choose BMC and benefit from:

- fast, convenient online submission

- thorough peer review by experienced researchers in your field

- rapid publication on acceptance

- support for research data, including large and complex data types

- gold Open Access which fosters wider collaboration and increased citations

- maximum visibility for your research: over $100 \mathrm{M}$ website views per year

At $\mathrm{BMC}$, research is always in progress.

Learn more biomedcentral.com/submissions 